УДК 624.21

\title{
CHOICE OF OPMIMUM MATERIAL FOR STRENGTHENING THE ENTRANCE EDGES OF STEAM TURBINE ROTOR BLADES
}

\author{
D. Gluschcova, Prof., D. Sc. (Eng.), E. Grinchenko, Eng., \\ Ph. D. (Eng.), Ye. Voronova, Assoc. Prof., \\ Kharkov National Automobile and Highway University
}

\begin{abstract}
The influence of electrode material on the state of surfacing layer of steam turbine rotor blades is researched. The strengthened layer was produced by electro-spark alloying, using alloy T15K6 and steel 15X11MФW. The microstructure, microhardness and thickness of surfacing layers were investigated. The advantages of steel $15 X 11 M \Phi W$ for strengthening the entrance edges of steam turbine rotor blades which makes it possible to simultaneously harden both the entrance edges of rotor blades as well as increase their erosive resistance are grounded.
\end{abstract}

Key words: electro-spark alloying, electrode, surfacing layer, microstructure, microhardness, strengthening.

\section{ВЫБОР ОПТИМАЛЬНОГО МАТЕРИАЛА ДЛЯ УПРОЧНЕНИЯ ВХОДНЫХ КРОМОК РАБОЧИХ ЛОПАТОК ПАРОВЫХ ТУРБИН}

\author{
Д.Б. Глушкова, проф., д.т.н., Е.Д. Гринченко, инж., Е.М. Воронова, доц., \\ Харьковский национальный автомобильно-дорожный университет
}

Аннотация. Исследовано влияние материала электрода на состояние наплавленного слоя рабочих лопаток паровых турбин. Упрочненный слой формировался электроискровым легированием сплавом Т15К6 и сталью $15 X 11 М Ф Ш$ Исследовались микроструктура, микротвердость и толщина наплавленного слоя. Обоснованы преимущества стали $15 X 11$ МФШ для упрочнения входных кромок рабочих лопаток паровых турбин.

Ключевые слова: электроискровое легирование, электрод, наплавленный слой, микроструктура, микротвердость, упрочнение.

\section{ВИБІР ОПТИМАЛЬНОГО МАТЕРІАЛУ ДЛЯ ЗМЦНЕННЯ ВХІДНИХ КРАЙОК РОБОЧИХ ЛОПАТОК ПАРОВИХ ТУРБІН}

\author{
Д.Б. Глушкова, проф., д.т.н., О.Д. Грінченко, інж., Є.М. Воронова, доц., \\ Харківський національний автомобільно-дорожній університет
}

\begin{abstract}
Анотація. Досліджено вплив матеріалу електрода на стан наплавленого шару робочих лопаток парових турбін. Змічнений шар формувався електроіскровим легуванням сплавом Т15К6 $i$ сталлю $15 X 11$ МФШ. Досліджувались мікроструктура, мікротвердість і товщина наплавленого шару. Обтрунтовано переваги сталі $15 X 11$ МФШ для змічунення вхідних крайок робочих лопаток парових турбін.
\end{abstract}

Ключові слова: електроіскрове легування, електрод, наплавлений шар, мікроструктура, мікротвердість, зміцнення.

Introduction

Rotor blades of steam turbines determine the serviceability of the turbine. Their working con- ditions require high hardness of leading edges. Further, erosion damage reduces their resistance. To increase the service life of the blades the leading edges areexposed to such processing 
methods like hardening by high frequency currents and applicationof the widely used alloy T15K6 based on carbides $T i$ and $W$ asareinforcing electrode. The binder for this alloy is Co.

\section{Analysis of publications}

However, the mode of operation of the blades is such that requires increased resistance to shockerosion, lack of adverse influence of coating formation parameters on mechanical properties, high corrosion properties.

Application of the above methods has limitations. Thus, using the high-frequency current makes it difficult to technically temper the radius blend from the blade airfoil portion to the bookshelf bandage and use of the widely applied alloy T15K6as a reinforcing electrode is limited due to the presence of cobalt - an element that as a result of activation forms long-lived isotopes, which reduce the erosion resistance of blades.

In connection with the above, the objective of the present work was to develop a method that would enable to simultaneously reinforce the leading edges of the blades and reduce their erosion resistance.

\section{Purpose and problem statement}

In the given paper there were tested two materials to be used as an electrode: alloy T5K16 and steel 15H11MFSH.

The electric spark method is based on the phenomenon of electric erosion of materials under spark discharge in a gaseous medium, the polar erosion product transport on the layer of modified structure and alloy. As a result of electrical breakdown of the interelectrode gap there occurs a spark, in which the flow of electrons leads to local heating of the electrode (anode) [1]. On the surface of the cathode under the influence of high thermal loads there is carried out mixing of both the cathode and the anode material that promotes the formation of proper adhesion between the substrate and the formed layer. Figure 1 shows the general scheme of the electrosparkalloying [ESA].

The composition of the doped layer may differ significantly from the composition of the raw materials. It is caused by the specifics of the ESA impact, which consists in the ultra-high heating and cooling rates, the contact of surfaces to each other and with the surrounding elements of the environment under pulse exposure to high temperatures and pressures.

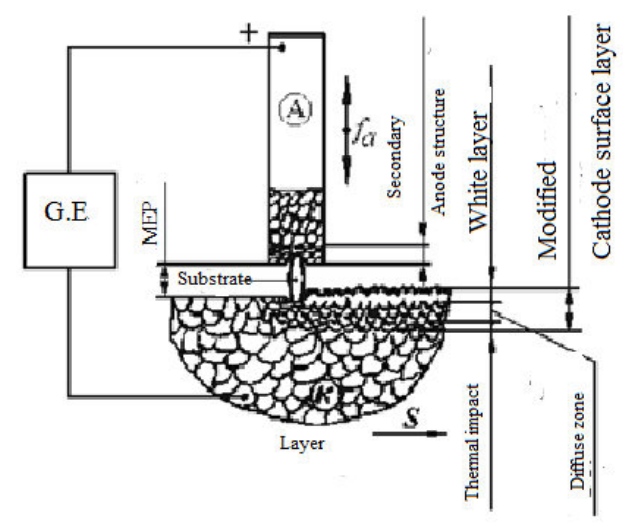

Fig. 1. General scheme of the electrospark alloying

The study was conducted, using samplesof steel $15 \mathrm{H} 11 \mathrm{MFSH}$ that was thermally treated to obtain the hardness of $285 \mathrm{NV}$ with removing the decarburized layer to the depth of $1 \mathrm{~mm}$ along the hardening plane. Workson strengthening the samples were carried out, using electrospark equipment EIL8A.

\section{Results of investigation and their discussion}

The microstructure of the base metal of specimens presents sorbitol with retaining orientation along martensitic planes. The structure of the samplesis of different uniformity, the structure contains grains of different etchability, and the size of the needles corresponds to 7-8 points (Fig. 2).

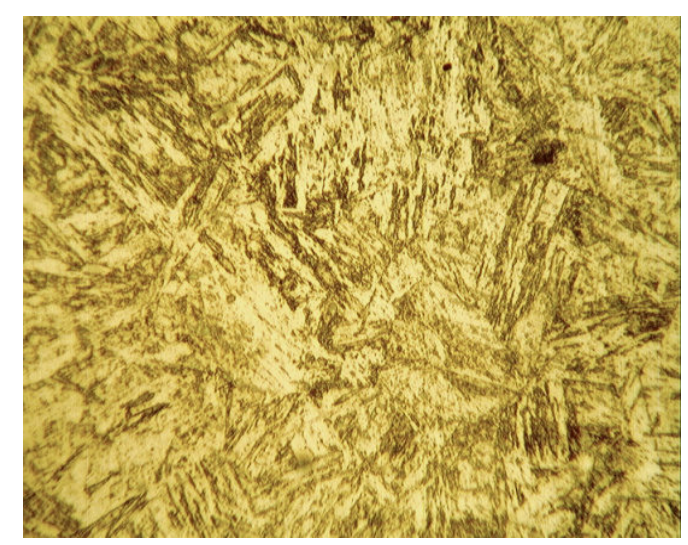

Fig. 2. Microstructure of the main sample metal

Control of the hardened surface is carried out by visual inspection with a magnifying glass with $\times$ $3, \times 10$ power. 
On the surface of the samples after hardening by both alloy T15K6and steel 15H11MFSH defects such as cracks were not revealed. Fig. 3 shows the appearance of the surface hardened by alloy T15K6. The layer is homogeneous, fine-grained and in some places there can be found small sizecraters.

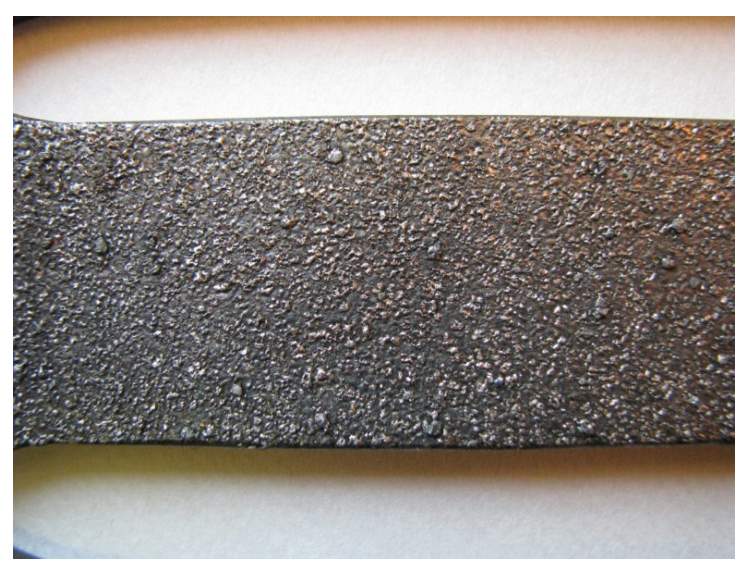

Fig. 3. The appearance of the sample surface strengthened by alloyT15K6

Fig. 4 shows the appearance of the surface hardened by steel $15 \mathrm{H} 11 \mathrm{MFSH}$. The layeris homogeneous, fine-grained, has small craters in small quantities.

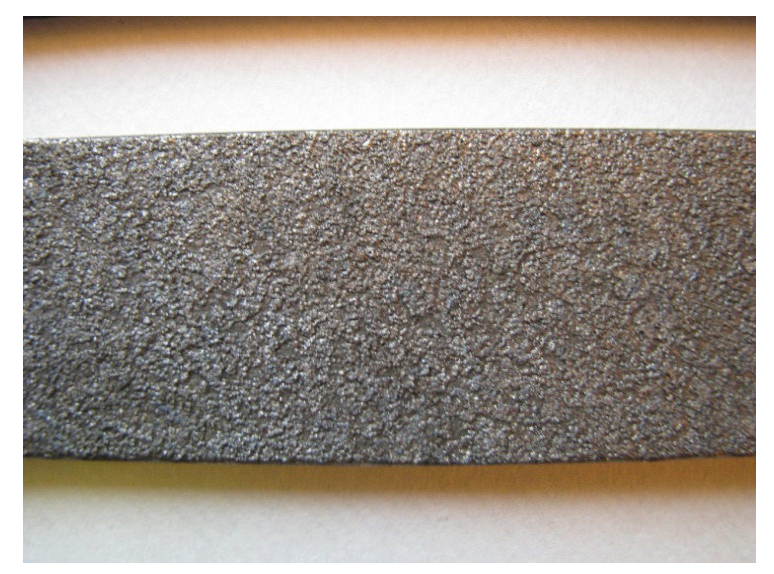

Fig. 4. The appearance of the sample surface, hardened by steel 15H11MFSH

To assess the quality of adhesion of doped layers with the substrate, the samples after hardening were tested according to the following scheme:

- samples №№1,2 were tested for bending at an angle of $90^{\circ}$, using a mandrel $R=20 \mathrm{~mm}$;

- samples №№ 3,4 were tested for bending at an angle of $70^{\circ}$, using a mandrel $R=40 \mathrm{~mm}$.

The test results are shown in Table 1 .
When viewingthebends the peel of the hardened layer from the base metal was not detected. Measurement of the thickness of the hardened layer was carried out in sections, manufactured according to the cross-sectional plane of the sample.

Table 1 Bending Test Results

\begin{tabular}{|c|c|c|c|}
\hline $\begin{array}{c}\text { Sample } \\
\text { brand }\end{array}$ & Material & $\begin{array}{c}\text { Test } \\
\text { results }\end{array}$ & Notes \\
\hline 1 & T15K6 & $\begin{array}{c}\text { No } \\
\text { ruination }\end{array}$ & $\begin{array}{c}\text { in the place of } \\
\text { bending } \\
\text { detected tears }\end{array}$ \\
\hline 2 & $15 \times 11 \mathrm{M} \amalg$ & $\begin{array}{c}\text { No } \\
\text { ruination }\end{array}$ & $\begin{array}{c}\text { in the place of } \\
\text { bending } \\
\text { detected tears }\end{array}$ \\
\hline 3 & $15 \times 11 \mathrm{M} \Phi \amalg$ & No \\
ruination & $\begin{array}{c}\text { in the place of } \\
\text { bending no } \\
\text { detected tears }\end{array}$ \\
\hline 4 & $15 \times 11 \mathrm{M} \Phi \amalg$ & $\begin{array}{c}\text { No } \\
\text { ruination } \\
\text { in the place of } \\
\text { bending no } \\
\text { detected tears }\end{array}$ \\
\hline
\end{tabular}

The surface hardened layer is characterized by heterogeneity of the layer thickness, but the average value of the thickness in case of hardening by alloy T15K6 and steel $15 \mathrm{H} 11 \mathrm{MFSH}$ is virtually identical (Fig. 5).

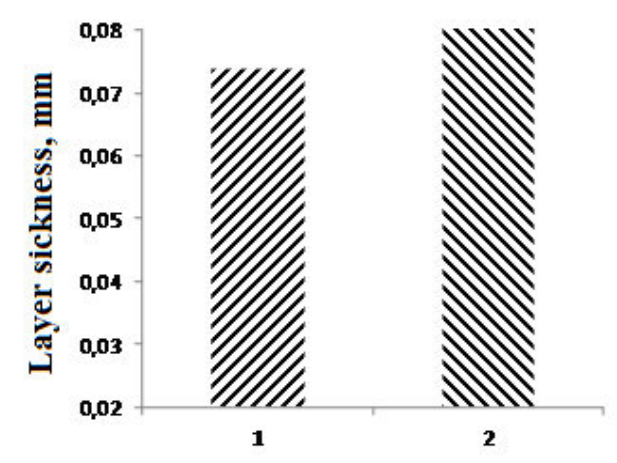

Fig. 5. Histograms of the mean values of the hardened layer thickness: 1 - by alloy T15K6; 2 - by steel steel 15H11MFSH

Study of the microstructure of the deposited layer showed that the structure is homogeneous, almost no etchability. In some places there were detected individual pores. When surfacing by steel $15 \mathrm{H} 11 \mathrm{MFSH}$, the layer structure is of mainly dendritic structure. In the surface layer of the base metal under high temperatures there was observed the formation of the light etchabilityzone formed by diffusion of the electrode ma- 
terial into the sample depth, and the darketchability zone of under alloying. In some places there were detected pores.

Fig. 6 shows histograms of microhardness measurement in the zone «hardened layer - base metal» of the samples under study.

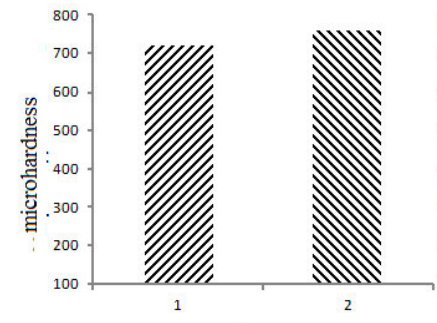

A
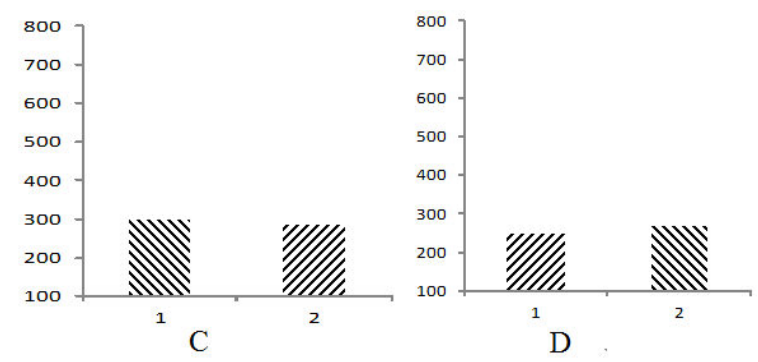

Fig. 6. Histograms of microhardness measurement in samples hardened by alloy T15K6 (1) and steel 15H11MFSH (2): a deposited layer; $\mathrm{b}$ - transition (diffusion) zone; c - HAZ $(\sim 0,05 \mathrm{~mm}$ from the border $)$; - HAZ $(\sim 0,1 \mathrm{~mm}$ from the border $)$

As it follows from the above histograms, in all areas the micro-hardness at hardening by alloy T15K6and steel $15 \mathrm{H} 11 \mathrm{MFSH}$ is practically identical.

\section{Conclusions}

When there was performed visual inspection and carried out metallographic analysis of samples reinforced by the electrospark method, using the equipment EIL 8A by electrodes made of steel 15H11MFSH and hard alloyT15K6 cracks were not revealed.

When conducting the bending test, none of the samples, hardened by both the solid alloy T15K6 and steel 15H11MFSH, failed.

On examination of the bends, the peel of the hardened layer from the base metal was not detected.
The average thickness of the surface layer hardened by both alloy T15K6 and steel 15H11MFSH was virtually identical.

The microhardness of the deposited layer, the transition zone, HAZ at different distances from the border when using both the hardened alloy T15K6 and steel 15H11MFSH do not practically differ.

6. Based on these studies it is recommended to replace the applied reinforcing electrode made of alloy T15K6 and steel 15H11MFSH to increase the hardness of the leading edges of steam engine rotor blades.

\section{References}

1. Мулин Ю.И. Электроискровое легирование рабочих поверхностей инструментов и деталей машин электродными материалами, полученными из минерального сырья / Ю.И. Мулин, А.Д. Верхотуров. - Владивосток: Дальнаука, 1999. $-110 \mathrm{c}$.

2. Современные методы упрочнения поверхностей деталей машин. Аналитический обзор // Научно-технический прогресс в машиностроении / под ред. К.В. Фролова. - 2009. - Вып. 9.1. - С. 205-271.

3. Костецкий Б.И. Трение, смазка и износ в машинах / Б.И. Костецкий. - К.: Техника, 2000. $-396 \mathrm{c.}$

4. Большаков В.И. Об эффективности защитных покрытий деталей газотурбинных двигателей / В.И. Большаков, В.И. Харченко, В.Н. Журавель // Перспективные задачи современной науки: сб. науч. тр. - 2002. - C. 109-116.

5. Большаков В.И. Етапи ідентифікації параметричних технологій та шляхи їхреалзації / В.И. Большаков, В.М. Волчук, Ю.У. Дубров // Вісник НАН України, 2013. - № 8. - С. 66-72.

\section{References}

1. Mulin Yu.I., Verhoturov A.D. Elektroiskrovoe legirovanie rabochih poverhnostey instrumentov i detaley mashin elektrodnymi materialami, poluchennymi iz mineralnogo syrya. [Electro-spark doping of working surfaces of tools and machine parts by electrode materials obtained from minerals. Vladivostok, Dalnauka Publ., 1999. - 110 p.

2. Sovremennye metody uprochneniya poverhnostey detaley mashin. Analiticheskiy ob- 
zor [Modern methods of hardening the surfaces of machine parts, Analytical review] Nauchno-tehnicheskiy progress $v$ mashinostroenii / pod red. K.V. Frolova. [Scientific and technological progress in engineering, ed. K. Frolov]. 2009. Vol. 9.1. pp. 205-271.

3. Kostetskiy B.I. Trenie, smazka i iznos $v$ mashinah. Friction, lubrication and wear in machines. Kyiv, Engineering Publ., 2000. $396 \mathrm{p}$.

4. Bolshakov V.I., Harchenko V.I., Zhuravel V.N. Ob effektivnosti zaschitnyh pokrytiy detaley gazoturbinnyh dvigateley. [On the effectiveness of protective coatings of gas turbine engine part], Perspektivnye zadachi sovremennoy nauki: sb. nauch. tr. [Advanced problems of modern science: Collection of scientific works]. 2002. pp. 109-116.

5. Bolshakov V.I., Volchuk V.M., Dubrov Yu. U. Etapy identifikatsiy parametrichnyh tehnologiy ta shliahy yih realizatsiy [Stages of parametric technology identification and ways of their identification]. Visnyk NAN Ukrayiny, 2013. Vol. 8. pp. 66-72.

Рецензент: В.Г. Солодов, профессор, д.т.н. ХНАДУ. 